\title{
Identification and Assemblage Types of Giardia duodenalis from Patients in Thrace, Turkey
}

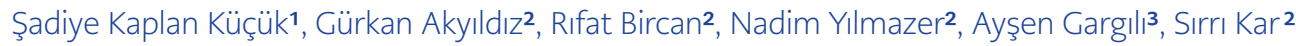 \\ 1 Microbiology and Parasitology Laboratory, Tekirdağ Central State Hospital, Tekirdağ, Turkey \\ 2 Department of Biology, Namık Kemal University, Tekirdağ, Turkey \\ 3 Department of Basic Health Sciences, Marmara University School of Health Sciences, Istanbul, Turkey
}

\begin{abstract}
Objective: Giardiasis is a common disease, and clinical forms can vary based on the assemblage types of the parasite. Detailed information on the subgenotypes may indicate the transmission routes and enlighten the gaps in the epidemiology of the disease. This study aims to reveal the occurrence of giardiasis in Thrace, Turkey, and assemblage types of Giardia duodenalis.

Materials and Methods: In total, 573 stool samples taken from the individuals applied to Tekirdağ Central State Hospital in 2009, were examined by wet-mount and zinc sulfate floatation methods. Giardia-positive 26 samples and 64 samples taken from the individuals with gastrointestinal complaints were analyzed by nested PCR-RFLP to differentiate the assemblage types. Sequence analysis was employed for confirmation of assemblage types and subgenotypes.

Results: Giardia spp. cysts were detected in $3.66 \%$ and $4.54 \%$ of the samples with wetmount and zinc sulphate floatation techniques respectively. A total of 27 samples were found positive by nested PCR-RFLP out of 90 samples. Fifteen samples were determined as assemblage A, 2 and 10 samples as B and B/E mix respectively. Sequence analysis showed that the latter assemblage (B/E mix) as A3-B3 mix.

Conclusion: Fast identification techniques, namely zinc sulphate flotation can be used for screening stool samples in order to determine Giardia cysts with considerably high sensitivity and specificity. Based on this method, the occurrence rate of giardiasis was found as $4.54 \%$ in the studied group. DNA sequencing is necessary to distinguish assemblages and confirm the results of PCR-RFLP.
\end{abstract}

Keywords: Giardia duodenalis, assemblage, subgenotype, human, Turkey

\section{INTRODUCTION}

$\mathrm{T}$ he genus Giardia includes six species based on the morphological features of trophozoite and cyst forms. Of these, Giardia varani is found from water monitor Varanus salvator, while Giardia agilis, Giardia ardeae and Giardia psittaci, Giardia microti and Giardia muris, and Giardia duodenalis from amphibians, birds, rodents, and mammals, respectively (1). Giardia duodenalis (syn. Giardia intestinalis, Giardia lamblia)
Corresponding Author: Ayşen Garglı

E-mail:

aysen.gargili@marmara.edu.tr

Received: February 6, 2019

Accepted: April 30, 2019

Published: May 30, 2019

Suggested citation: Kaplan Küçük S, Akyıldız G, Bircan R, Yllmazer N, Gargilı A, Kar S. Identification and assemblage types of Giardia duodenalis from patients in Thrace, Turkey. Infect Dis Clin Microbiol 2019; 1: 6-13.

DOI: $10.5152 / \mathrm{idcm} .2019 .19001$ 
of zoonotic importance infects humans and more than 40 other mammals (2). Molecular studies and antigenic analyses revealed that $G$. duodenalis comprises at least seven assemblages which are geno/ phenotypically distinct, but morphologically similar (3-5). Assemblages A and B which are considered potentially zoonotic are found in both humans and animals $(6,7)$, such as non-human primates, canids, felines, rabbits, beavers, muskrats, mustelids, rodents, marsupials, wild ruminants and livestock animals (8). However, the other assemblages are considered principally host specific, and of those, assemblage $C$ and $D$ have been described in dogs, cats, coyotes and wolves, E was isolated in hoofed animals such as cattle, sheep, goats, pigs, water buffaloes and mouflons, $\mathrm{F}$ is specific for cats, $\mathrm{G}$ is found exclusively in mice and rats, and in cats as well, and $\mathrm{H}$ was detected in pinnipeds faeces $(8,9)$.

Cysts of the parasite, which inhabits small intestine and has a monoxenous life cycle, become infectious shortly after they are excreted with the faeces, surviving for months in aqueous environments, and a few oocysts can cause infection when contaminated water and food are taken orally. These aspects matter in epidemiologic characteristics of this zoonotic agent (1). Giardiasis is a common disease throughout the world, and 280 million people develop symptomatic Giardia infection annually, thus being considered a global endemic $(1,5)$. On the other hand, the prevalence of the parasite considerably differs in distinct populations and

\section{HIGHLIGHTS}

- This study provides up-to-date information on the occurrence and prevalence of giardiasis in a previously unstudied region.

- Obtained results emphasize that subgenotyping of $G$. duodenalis can reveal the transmission ways of the infection in the studied region and suggest implications for protective precautions.

- Results show that the fast diagnostic techniques such as zinc sulphate flotation can be a choice for detection of the parasite. On the other hand, the most reliable technique for differentiation of the assemblage types and subgenotypes was determined based on DNA sequencing. geographic regions. It was reported that this parasite annually infects around 200 million people in developing countries, especially in Asia, Africa and Latin America (7). However, incidence rates observed in developed countries ranges from 1-7\% (5). For instance, $20-30 \%$ of humans are the transmitters in developing countries while annual giardiasis cases are around 1200-1500 in Sweden which is over a certain socioeconomic threshold (10).

This study aims to reveal the occurrence of giardiasis in Thrace, European part of Turkey, and its incidence, along with the establishment of assemblages of the causative agent $G$. duodenalis by providing descriptive characteristics of subgenotypes.

\section{MATERIALS AND METHODS}

\section{Stool sampling}

Single stool samples were collected from 573 of the patients who applied to Tekirdağ Central State Hospital during a one-year-period, 2009, based on gastrointestinal complaints, clinical examinations and macroscopic features of stool. Patients genders, ages, addresses and other information including clinical findings and other diseases, if any, were recorded. Samples were transferred into $15 \mathrm{ml}$ clean plastic tubes, mixed with potassium dichromate solution to a final concentration of $2.5 \%$ and were stored at $+4^{\circ} \mathrm{C}$ until examination within a month using native and floatation techniques.

An ethics committee approval was not provided in this study because the regulation on clinical research entered into force on 19 August 2011 (Official Gazette number 28030) in Turkey, and ethics committees within the scope of this regulation began to be formed thereafter. However, informed consents of the patients were taken after explaining to them the details of our study.

\section{Wet-mount and zinc sulfate floatation techniques}

Microscopic examination of a wet-mount with saline of fresh stools was performed at x10 and x40 magnification. Zinc sulfate (ZnSO4; 33\%) floatation concentration technique (11) was also used to examine the stools. After the completion of the microscopic examination, the samples were stored at $-20^{\circ} \mathrm{C}$ until DNA extraction. 


\section{DNA extraction}

DNA was extracted from a total of 90 stool samples including 26 samples which were positive by microscopic examination, and 64 samples which were suspected as giardiasis according to both stool morphology and clinical suspicion (12-14). QIAamp DNA Stool Mini Kit (Qiagen, Germany) was employed based on the manufacturer's instructions. Extracted DNAs were stored at $-20^{\circ} \mathrm{C}$ until use.

\section{Nested PCR}

A 753 bp fragment of the $\beta$-giardin gene was amplified using the primers described by Cacciò et al. (15). PCR amplification was performed in a final volume of $25 \mu \mathrm{L}$ containing $10 \mathrm{pmol}$ each appropriate primer (G7 F5'-AAGCCCGACGACCTCACCCGCAGTGC-3' forward and G759R 5'-GAGGCCGCCCTGGATCTTCGAGACGAC-3' reverse), $200 \mu \mathrm{M}$ of dNTPs, $1.5 \mathrm{mM}$ $\mathrm{MgCl}_{2}, 1 \mathrm{U}$ Taq polymerase and 10X reaction buffer (500 mMTris-HCl, pH 8.8, $160 \mathrm{mM}\left(\mathrm{NH}_{4}\right) \mathrm{SO}_{4}$ and $0.1 \%$ Tween ${ }^{\circledR} 20$ ) (MBI Fermantas, Lithuania) and 100 ng DNA. The PCR protocol consisted of an initial denaturation at $95^{\circ} \mathrm{C}$ for $15 \mathrm{~min}$, annealing at $60^{\circ} \mathrm{C}$ for $30 \mathrm{sec}$ and extension at $72^{\circ} \mathrm{C}$ for $60 \mathrm{sec}$ each, for 35 cycles, with a final 7 min extension at $72^{\circ} \mathrm{C}$. PCR products of 753bp were obtained and separated on a $2 \%$ agarose gel, stained with ethidium bromide and visualized with UV transillumination. Nested amplification was performed in a final volume of $25 \mu \mathrm{L}$ containing $10 \mathrm{pmol}$ each appropriate primer (BG1F 5'-GAACGAGATCGAGGTCCG-3' forward and BG2R 5'-CTCGACGAGTTCGTGTT-3' reverse), $200 \mu \mathrm{M}$ of dNTPs, $1.5 \mathrm{mM} \mathrm{MgCl}_{2}$, $1 \mathrm{U}$ Taq polymerase and 10X reaction buffer (500 mMTris- $\mathrm{HCl}, \mathrm{pH}$ 8.8, $160 \mathrm{mM}\left(\mathrm{NH}_{4}\right) \mathrm{SO}_{4}$ and $0.1 \%$ Tween $\left.{ }^{\circledR} 20\right)(\mathrm{MBI}$ Fermantas, Lithuania) and $100 \mathrm{ng}$ DNA. The thermal cycling was carried out in a TC-Plus Thermocycler (Techne, Cambridge, UK) under the following conditions, initial denaturation at $95^{\circ} \mathrm{C}$ for $15 \mathrm{~min}$, 35 cycles at $95^{\circ} \mathrm{C}$ for $30 \mathrm{sec}$ annealing at $55^{\circ} \mathrm{C}$ for 30 sec and extension at $72^{\circ} \mathrm{C}$ for $60 \mathrm{sec}$ followed by a final 7 min extension at $72^{\circ} \mathrm{C}$. PCR products of 511 bp were obtained and separated on a $2 \%$ agarose gel, stained with ethidium bromide and visualized with UV transillumination (16).

RFLP analysis of nested PCR-positive samples $10 \mu \mathrm{L}$ of the amplification products were digested with 10U of BsuRI (HaeIII) restriction enzyme (MBI
Fermantas, Lithuania) overnight at $37^{\circ} \mathrm{C}$ and separated on a $12 \%$ polyacrylamide gel, stained with ethidium bromide, visualized with UV transillumination, and the results were evaluated according to Lalle et al. (16).

\section{DNA sequence analysis of nested PCR-positive samples}

$11 \mathrm{bp}$ samples were sequenced bidirectionally using the same primer sets given in nested PCR step. For this purpose, the PCR products were purified with PEG 4000 as described by Rosenthal et al. (17), subsequently sequenced by using Big Dye-terminator chemistry (Beckmann Coulter, USA) according to the manufacturer's instructions. For this purpose, the sequencing reaction was performed in a Techne TC-Plusthermocycler at $96^{\circ} \mathrm{C}$ for 20 sec, and annealing at $50^{\circ} \mathrm{C}$ for $20 \mathrm{sec}$ and extension at $60^{\circ} \mathrm{C}$ for $4 \mathrm{~min}$ each, for 30 cycles. Analyses of sequencing reactions were performed on an automatic sequencer Beckman Coulter Genome Lab Genetic Analyzer (Beckmann Coulter, USA).DNA sequences and chromatograms obtained were examined by using GenomeLab GeXP Genetic Analysis System Version 10.2 DNA sequencing program (Beckman Coulter, USA). The precise assemblages of the Giardia-positive samples were determined with comparing the sequencing results with the reference sequence published by Cacció et al. (15) by using the web-based bioinformatic programme Clustal Omega (http://www.ebi.ac.uk/Tools/msa/ clustalw2/).

\section{RESULTS}

\section{Macroscopic features of the samples}

The gender of the patients was 301 males (52.53\%) and 272 females (47.47\%), with an average age of 19.03 (ranging from 3 days to 97 years old). Clinically, 427 of the patients demonstrated symptoms of a gastrointestinal disorder. Specifications of the stool samples such as colour, content texture and assemblage types of the Giardia-positive patients with various clinical presentations were given in the Table 1.

\section{Findings of microscopic examination}

Native stool examination at $\times 40$ magnification detected Giardia spp. cysts in 21 samples (3.66\%). With 
Table 1.Characteristics of the patients and the samples regarding positive results.

\begin{tabular}{|c|c|c|c|c|c|c|}
\hline Age & Gender & $\begin{array}{c}\text { Clinical } \\
\text { presentation }\end{array}$ & $\begin{array}{l}\text { Native microscopy } \\
\text { (x40) }\end{array}$ & $\begin{array}{l}\text { Colour and content } \\
\text { changes in stool }\end{array}$ & $\begin{array}{c}\text { Zinc sulphate } \\
\text { flotation for } \\
\text { Giardia (x40) }\end{array}$ & $\begin{array}{c}\text { Assemblage } \\
\text { type } \\
\text { (sequencing }\end{array}$ \\
\hline 1 & M & Pneumonia & Giardia (+), Yeast $(20<)$ & Yellowish, hard & +++ & A \\
\hline 2 & M & Pneumonia & Giardia (+), Yeast $(20<)$ & Yellowish brown, hard & +++ & A \\
\hline 2 & M & Gastroenteritis & Giardia (+) & Normal & + & $A B$ \\
\hline 3 & M & Cough & Yeast $(20<)$ & Brown, soft & +++ & B \\
\hline 4 & M & Urinary infection & Giardia (+) & Brown, hard & +++ & A \\
\hline 4 & M & Asthma & $\begin{array}{c}\text { Giardia }(+), \\
\text { Leucocytes }(20<), \\
\text { Erythrocytes }(20<)\end{array}$ & Mucous & + & A \\
\hline 5 & $\mathrm{~F}$ & Malnutrition & Giardia (+) & Normal & + & B \\
\hline 5 & M & Abdominal pain & Giardia (+) & Watery & +++ & $A B$ \\
\hline 6 & M & Abdominal pain & Giardia (+) & Hard & + & $A B$ \\
\hline 8 & $\mathrm{~F}$ & Abdominal pain & Giardia (+) & Hard & +++ & A \\
\hline 8 & $\mathrm{~F}$ & Abdominal pain & Negative & Hard & ++ & A \\
\hline 8 & $\mathrm{~F}$ & Abdominal pain & Giardia (+) & Fatty, soft & + & $A B$ \\
\hline 10 & $\mathrm{~F}$ & Abdominal pain & Giardia (+) & Normal & +++ & A \\
\hline 10 & M & Abdominal pain & Negative & Hard & ++ & A \\
\hline 10 & M & Nausea-vomiting & Negative & Watery & Negative & $A B$ \\
\hline 10 & M & Abdominal pain & Giardia (+) & Green, soft & +++ & $A B$ \\
\hline 11 & $\mathrm{~F}$ & Abdominal pain & Giardia (+) & Normal & +++ & A \\
\hline 12 & M & Nausea-vomiting & Negative & Soft & + & $A B$ \\
\hline 19 & $\mathrm{~F}$ & No symptoms & Giardia (+) & Fatty, soft & +++ & A \\
\hline 21 & M & No symptoms & Giardia (+) & Soft & +++ & A \\
\hline 24 & M & Reflux & Negative & Normal & +++ & $A B$ \\
\hline 26 & M & No symptoms & Giardia (+) & Soft & +++ & A \\
\hline 26 & $\mathrm{~F}$ & Viral enfection & Giardia (+) & Hard & + & A \\
\hline 39 & $\mathrm{~F}$ & No symptoms & Giardia (+) & Soft & +++ & A \\
\hline 52 & $\mathrm{~F}$ & Bronchitis & $\begin{array}{c}\text { Giardia (+), } \\
\text { Erithrocytes (20<) }\end{array}$ & Bloody & +++ & A \\
\hline 57 & M & Gastroenteritis & Giardia (+) & Dark brown & + & $A B$ \\
\hline 59 & $\mathrm{~F}$ & Gastroenteritis & Giardia (+) & Soft & +++ & $A B$ \\
\hline
\end{tabular}



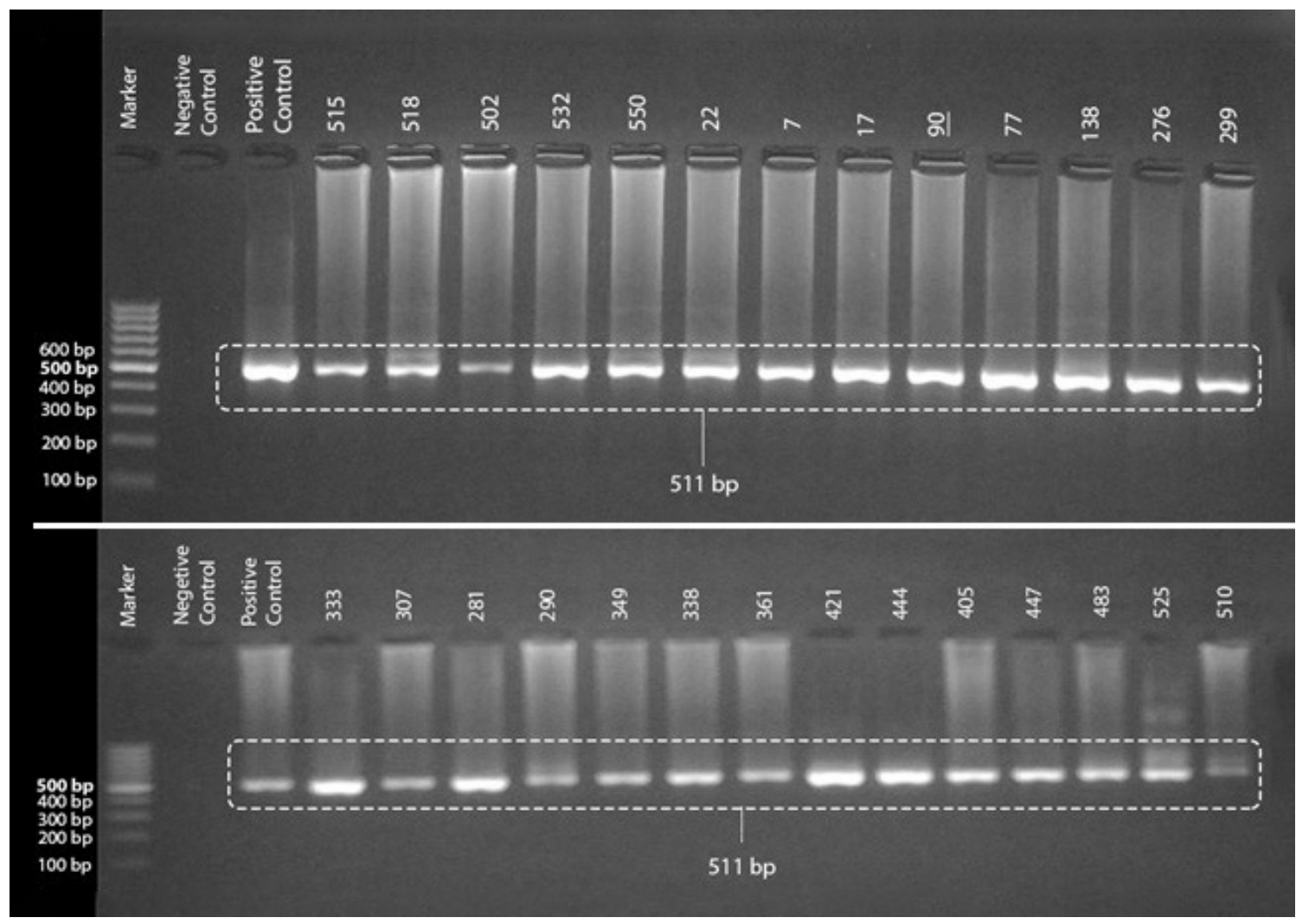

Figure 1. PCR products (511 bp) of nested-PCR positive samples visualized on $2 \%$ agarose gel. The numbers above the wells were the assigned protocol numbers for the samples.

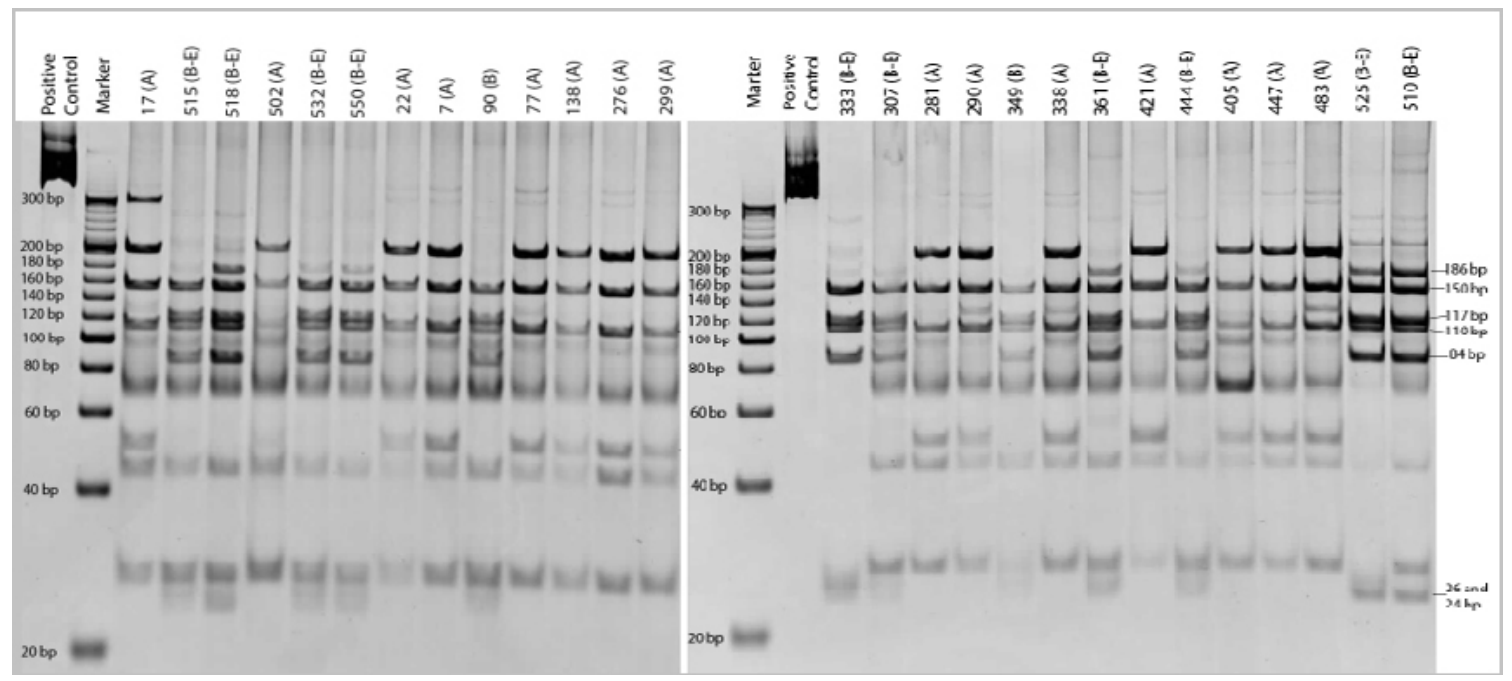

Figure 2. Haell restriction products of 27 samples visualized by PAGE (12\%).The assigned protocol numbers and assemblage types of the samples were given above the wells. 
zinc sulphate floatation technique, five more samples were found to be positive for Giardia spp. cysts, reaching a total of 26 positive samples (4.54\%). Sensitivity and specificity of zinc sulphate floatation technique were $96.30 \%(26 / 27)$ and 100\% (63/63), respectively, in consideration of nested PCR. The number of cysts determined at $\mathrm{x} 40$ magnification was 1-2, 3-5, and over 5 per microscopic field for 8 , 2 and 16 samples, respectively.

\section{Nested PCR findings}

Out of 90 samples, consist of 26 which were found to be positive by microscopic examination and an additional 64 selected based on macroscopic features, screened by nested PCR. A total of 27 samples, 26 of which were found to be positive by microscopic examination, showed specific bands at $511 \mathrm{bp}$ on agarose gel (Figure1).

\section{RFLP analysis}

After the restriction analysis of the $\beta$-giardin gene from the 27 positive samples with HaeII digestion, the results were evaluated according to Lalle et al. (15), and 15 samples were determined as assemblage A genotype, 10 samples as assemblage B-E mix and 2 samples as assemblage B (Figure 2).

\section{DNA Sequence Analysis of the $\beta$-giardin gene}

The obtained DNA sequences from the clinical

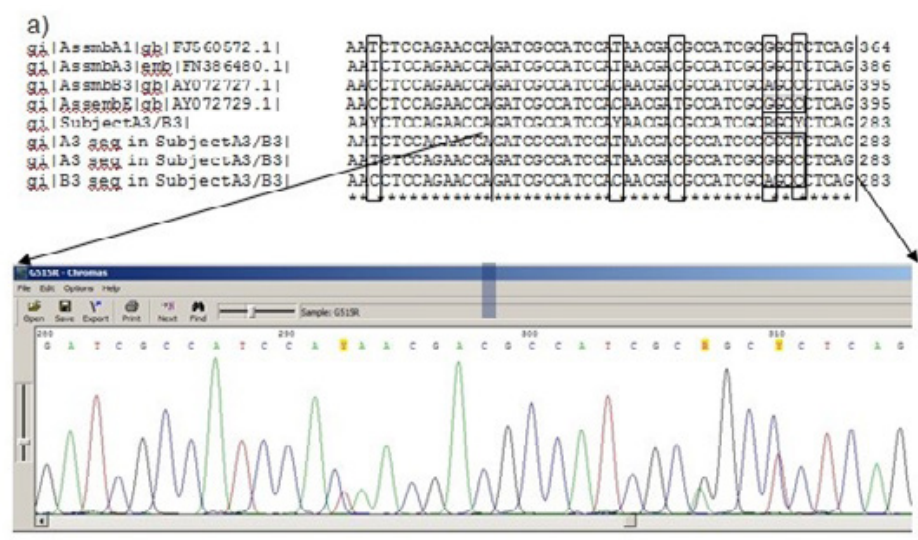

Figure 3. One-base difference in the sample DNA carrying assemblage A3 genotype, which creates a specific Haell restriction site for assemblage $E$ in RFLP analysis. The possible sequences belonging to the subject are; original sequence of assemblage A3“ 5 '-GATCGCCATCCATAACGACGCCATCCCGCCT CTCAC3"” or mutated sequence "5'-GATCCCCATCCATAACGACCCCATCCCC GCCCTCAG3"' which creates a restriction site for Haell and results in falsepositive E3 assemblage instead of A assemblage in PCR-RLFP method. samples were compared with reference sequences, as described by Cacció et al. (14) by using the webbased program Blast. Then the assemblages of the clinical samples were determined as A3, B3 and A3/ $B 3$ mix instead of assemblage $B / E$ mix with a onebase difference among $A$ and $B$ assemblage reference sequences. Afterwards, the sample sequences were compared with reference sequences in GenBank (GenBank no: FN386480.1 for assemblage A3; FJ560572.1 for assemblage B3 and AY072729.1 for assemblage E) by using the web-based CLUSTAL 2.1 multiple sequence alignment program. The one-base difference which creates assemblage $\mathrm{E}$ restriction site for RFLP analysis, which causes false-positive $\mathrm{E}$ assemblage determination instead of A assemblage in PCR-RFLP method, was shown in Figure 3.

\section{DISCUSSION}

Most of the studies on giardiasis in Turkey are based on microscopic examination of stool samples, reporting a positivity ranging between $0.8-54.8 \%$ (18). The present study detected a positivity of $3.66 \%$ by native examination and of $4.54 \%$ by zinc sulfate floatation concentration technique. These rates are in concordance with the prevalence rates of giardiasis in both Turkey and worldwide. It is known that the prevalence of giardiasis is associated with socioeconomic status, and being lower (0.4-7.5\%) in developed countries and higher (8-30\%) in developing countries (1).

Assemblages A and B are the main agents responsible for human giardiasis, the latter being more prevalent. Indeed, the mean prevalence rate is $60 \%$ for assemblage B, while $35 \%$ and $5 \%$ for assemblages $\mathrm{A}$ and $\mathrm{A}-\mathrm{B}$ mix, respectively in worldwide $(7,9$, 19-23). However, the occurrence of assemblages may vary from region to region. For example, the prevalence rate of assemblages A and B was found to be $73 \%$ and $2.5 \%$ in Thailand (24), $52 \%$ and $22 \%$ in Ethiopia (25), and $65 \%$ and $27.5 \%$ in Syria (26). Up to date, a few genotyping studies on giardiasis have been performed in Turkey. Assemblage A was the dominant genotype in giardiasis cases in the provinces of Kocaeli, Sivas, Manisa, and Aydin with the prevalence rates of 50\%, 53\%, 70.37\%, and $80 \%$ respectively. However, the prevalence rate of 
assemblage B was $56.82 \%$ in Ankara where it was predominated, and between $20 \%$ and $31.8 \%$ in other provinces (27-31).

The role of animals in the epidemiology of human giardiasis is still under debate. Host distribution of assemblage $B$ is restricted to humans, and therefore humans are its primary source while assemblage $\mathrm{A}$ is found in a wide range of mammals, and its prevalence is higher in them than in humans. As a result of these variations, assemblage $A$ is incriminated as an important zoonotic agent. In our study, among the 27 positive samples, 15 were found as assemblage $\mathrm{A}$, and only one patient among this group was living in the rural area. Although the majority of the cases were from urban areas, the occurrence of assemblage A as dominant causative agent indicates a possible zoonotic transmission. Livestock which was reported as the primary source of assemblage A (32) are not raised in urban areas of Tekirdag; on the other hand, other domestic animals may play a significant role in transmission. Dogs and calves were reported as main animals in terms of zoonotic transmission for subgenotypes A1, A2, A3, A4 and B3 which are found in humans (33). In our study, subgenotypes A3 and B3 were detected in all positive samples suggesting a possible zoonotic transmission. In addition, contaminated city water and/ or fruit and vegetables brought to the city markets from the villages should be considered as the way of transmission. Assemblages C, D, E, F and G show strong host specificity, having narrow host ranges, and there is no evidence that they are of importance to human health (7). Assemblage $\mathrm{E}$ is especially found in livestock including cattle sheep, goats and pigs, as well as known to occur in wild animals, cats, dogs and some other animals (32).

Some studies revealed that assemblage B is responsible for persistent infections in humans, whereas assemblage $\mathrm{A}$ is found in diarrhoea or subclinical cases $(13,14)$. However, studies in which different results were obtained are also available $(19,22)$. In our study, gastrointestinal symptoms were common in $33.33 \%$ of the assemblage A-positive patients whose stool consistency was hard (40\%) and normal (53.33\%).

As a conclusion, the presence of $G$. duodenalis should be considered in patients with gastrointestinal complaints, regardless of the stool consistency. Among the fast detection techniques, zinc sulphate flotation can provide reliable results for the evaluation of stool samples. Although RFLP-PCR may provide information on the assemblage types, accurate results and subtyping can be achieved by DNA sequencing at the most credible level. Assemblage types and subgenotypes may provide information for the transmission possibilities of the infectious agent.
Ethics Committee Approval: The ethics committee approval was not provided in this study because the regulation on clinical research entered into force on 19 August 2011 (Official Gazette number 28030) in Turkey, and ethics committees within the scope of this regulation began to be formed thereafter.

Informed Consent: Written informed consent was obtained after explaining to them the details of our study from the patients who participated in this study.

Peer-review: Externally peer-reviewed.

Author Contributions: Concept - S..K.K., G.A., R.B., N.Y., A.G., S.K.; Design - Ş.K.K., G.A., R.B., N.Y., A.G., S.K.; Supervision - Ş.K.K., G.A.,
R.B., N.Y., A.G., S.K.; Resources - Ş.K.K., G.A., R.B., N.Y., A.G., S.K.; Materials - Ş.K.K., G.A., R.B., N.Y., A.G., S.K.; Data Collection and/ or Processing - Ş.K.K., G.A., R.B., N.Y., A.G., S.K.; Analysis and/or Interpretation - S..K.K., G.A., R.B., N.Y., A.G., S.K.; Literature Search - S..K.K., G.A., R.B., N.Y., A.G., S.K.; Writing Manuscript - Ş.K.K., G.A., R.B., N.Y., A.G., S.K.; Critical Reviews - Ş.K.K., G.A., R.B., N.Y., A.G., S.K.

Conflict of Interest: The authors have no conflict of interest to declare.

Financial Disclosure: The authors declared that this study has received no financial support. 


\section{REFERENCES}

1 Feng Y, Xiao L. Zoonotic potential and molecular epidemiology of Giardia species and giardiosis. Clin Microbiol Rev 2011; 24: 110-40.

2 Monis PT, Cacció SM, Thompson RC. Variation in Giardia: towards a taxonomic revision of the genus. Trends Parasitol 2009; 25: 93-00.

3 Monis PT, Andrews RH, Mayrhofer G, Ey PL. Genetic diversity within the morphological species Giardia intestinalis and its relationship to host origin. Infect Genet Evol 2003; 3: 29-38.

4 Thompson RCA. The zoonotic significance and molecular epidemiology of Giardia and giardiasis. A review. Vet Parasitol 2004; 126: 15-35.

5 Weese JS, Anderson MEC, Fulford MB. Companion Animal Zoonoses, In Parasitic zoonoses. Weese SJ and Fulford M, editors USA: Wiley-Blackwell Publishing; 2011.

6 Giangaspero A, Berilli F, Brandonisio O. Giardia and Crptosporidium and public health: the epidemiological scenario from the Italian perspective. Parasitol Res 2007; 101: 1169-82.

7 Cacció SM, Ryan U. Molecular epidemiology of giardiasis. Mol Biochem Parasitol 2008; 160: 75-80.

8 Fantinatti M. Zoonotic potential of Giardia lamblia and control of giardiasis. Insights Vet Sci 2019; 3: 1-4.

9 Cacció SM, Thompson RC, McLauchlin J, Smith HV. Unravelling Cryptosporidium and Giardia epidemiology. Trends Parasitol 2005; 21:430-7.

10 Adam RD. Biology of Giardia lamblia. Clin Microbiol Rev 2001; 14: $447-75$

11 Zajac AM, Johnson J, King SE. Evaluation of the importance of centrifugation as a component of zinc sulfate fecal flotation examinations. J Am Anim Hosp Assoc 2002; 38: 221-4

12 Flanagan PA. Giardia; diagnosis, clinical course and epidemiology. A review. Epidemiol Infect 1992; 109: 1-22.

13 Homan WL, Mank TG. Human giardiasis: genotype linked differences in clinical symptomatology. Int J Parasitol 2001; 31: 822-6.

14 Mahdy AKM, Surin J, Wan KL, Mohd-Adnan A, Al-Mekhlafi MSH, Lim YAL. Giardia intestinalis genotypes: Risk factors and correlation with clinical symptoms. Acta Trop 2009; 12: 67-70.

15 Cacció SM, de Giacomo M, Pozio E. Sequence analysis of the $\beta$ giardin gene and development of a PCR-RFLP assay to genotype Giardia duodenalis cysts from human faecal samples. Int J Parasitol 2002; 32: 1023-30.

16 Lalle M, Pozio E, Capelli G, Bruschi F, Crotti D, Cacció SM. Genetic heterogeneity at the $\beta$-giardin locus among human and animal isolates of Giardia duodenalis and identification of potentially zoonotic subgenotypes. Int J Parasitol 2005; 35: 207-13.

17 Rosenthal A, Coutelle O, Craxton M. Large-scale production of DNA sequencing templates by microtitre format PCR. Nucleic Acids Res 1993; 21: 173-4

18 Ak M, Tanyüksel M, Dağcı H. Amoebiasis. Özcel'in Tıbbi Parazit Hastalıkları. Özcel MA, editor. Izmir, Turkey: Meta Basım; 2007. pp. 279-307.
19 Kohli A, Bushen OY, Pinkerton RC, Houpt E, Newman RD, Sears $\mathrm{CL}$, et al. Giardia duodenalis assemblage, clinical presentation and markers of intestinal inflammation in Brazilian children. Trans R Soc Trop Med Hyg 2008; 102: 718-25.

20 Franzén O, Jerlström-Hultqvist J, Castro E, Sherwood E, Ankarklev J, Reiner DS, et al. Draft genome sequencing of giardia intestinalis assemblage B isolate GS: is human giardiasis caused by two different species? PLoS Pathog 2009; 5: e1000560.

21 Ankarklev J, Jerlström-Hultqvist J, Ringqvist E, Troell K, Svärd SG. Behind the smile: cell biology and disease mechanisms of Giardia species. Nat Rev Microbiol 2010; 8: 413-22.

22 Breathnach AS, McHugh TD, Butcher PD. Prevalence and clinical correlations of genetic subtypes of Giardia lamblia in an urban setting. Epidemiol Infect 2010; 138: 1459-67.

23 Jerlström-Hultqvist J, Ankarklev J, Svärd SG. Is human giardiasis caused by two different Giardia species? Gut Microbes 2010; 1: 379-82

24 Traub RJ, Inpankaew T, Reid SA, Sutthikornchai C, Sukthana Y, Robertson ID, et al. Transmission cycles of Giardia duodenalis in dogs and humans in temple communities in Bangkok-a critical evaluation of its prevalence using three diagnostic tests in the field in the absence of a gold standard. Acta Trop 2009; 111: $125-32$

25 Gelanew T, Lalle M, Hailu A, Pozio E, Cacció SM. Molecular characterization of human isolates of Giardia duodenalis from Ethiopia. Acta Trop 2007; 102: 92-9.

26 Skhal D, Aboualchamat G, Al Mariri A, Al Nahhas S. Prevalence of Giardia duodenalis assemblages and sub-assemblages in symptomatic patients from Damascus city and its suburbs. Infect Genet Evol 2017; 47: 155-60

27 Aydin AF, Besirbellioglu BA, Avci IY, Tanyuksel M, Araz E, Pahsa A. Classification of Giardia duodenalis parasites in Turkey into groups A and B using restriction fragment length polymorphism. Diagn Microbiol Infect Dis 2004; 50: 147-51.

28 Balcioglu C, Kurt O, Sevil N, Dagci H, Tetik A, Ergunay K, et al. Genotyping of Giardia lamblia in a cohort of Turkish patients: a search for a relationship between symptoms and genotypes. Kafkas Univ Vet Fak Derg 2012; Suppl 18: SA.

29 Değerli S, Değerli N, Çeliksöz A, Özçelik S. Genotyping of Giardia intestinalis isolated from people living in Sivas, Turkey. Turk J Med Sci 2012; Suppl 42: S1.

30 Tamer GS, Kasap M, Er DK. Genotyping and phylogenetic analysis of Giardia duodenalis isolates from Turkish children. Med Sci Monit 2015; 21: 526-32.

31 Ertug S, Ertabaklar H, Ozlem Caliskan S, Malatyali E, Bozdoğan B. Genotyping of Giardia intestinalis strains isolated from humans in Aydin, Turkey. Mikrobiyol Bul 2016; 50: 152-8.

32 Geurden T, Geldhof P, Levecke B, Martens C, Berkvens D, Casaert S, et al. Mixed Giardia duodenalis assemblage A and E infections in calves. Int J Parasitol 2008; 38: 259-64.

33 Lalle M, Frangipane di Regalbono A, Poppi L, Nobili G, Tonanzi D, Pozio E, et al. A novel Giardia duodenalis assemblage A subtype in fallow deer. J Parasitol 2007; 93: 426-8. 